\title{
Wacław Branicki*
}

\section{AUTENTYCZNOŚĆ OSOBOWA \\ W PERSPEKTYWIE TEORII DEZINTEGRACJI POZYTYWNEJ}

\begin{abstract}
Problemy omówione w pierwszej części artykułu obejmują relacje między fenomenem autentyczności a wpływem farmakologii na psychikę człowieka oraz kwestią sztucznej inteligencji. W drugiej części artykułu poddany został analizie związek pojęcia autentyczności i naturalności. W trzeciej części powyższy problem przedstawiono w ramach koncepcji Kazimierza Dąbrowskiego. W czwartej części przeanalizowano wybrane elementy koncepcji śmierci w jej relacji do autentyczności w ujęciu Heraklita i Dąbrowskiego. W ostatniej części pracy poddano dyskusji tezę mówiącą o możliwości traktowania sztucznej inteligencji jako autentycznej osoby.
\end{abstract}

Słowa kluczowe: autentyczność osobowa, teoria dezintegracji pozytywnej, sztuczna inteligencja, śmierć

\section{ZARYS PROBLEMATYKI}

Problematyka autentyczności wymaga ponownej analizy, ponieważ pojawiają się hipotezy, wedle których w świetle nowych zjawisk zmienia się dotychczasowy sens tego pojęcia. Jedną z tych okoliczności jest dysponująca coraz większymi możliwościami sztuczna inteligencja. Tworzone są roboty, które mają duże zdolności do interakcji społecznych, takich jak symulowanie stanów emocjonalnych. Piszę tutaj o symulowaniu, choć niektórzy autorzy nie wahają się twierdzić, że nie ma istotnej różnicy między ekspresją emocjonalną ludzi i robotów. Sharon Turkle pisze, że podstawową przesłanką, na podstawie której uzasadnia się twierdzenie o istnieniu owej różnicy jest fakt, że reakcje maszyn są zaprogramowane przez człowieka, a zatem nie są one autentyczne. Jednak Turkle stara się podważyć to uzasadnienie, pisząc:

Podobnie jak roboty ludzie posiadają programy, które są podstawą naszych reakcji emocjonalnych. Jesteśmy ograniczeni przez mechanizmy nawet w naszych najbardziej emocjonalnych momentach (Turkle 2011: 137) $)^{1}$.

Każda reakcja opiera się na pewnym wzorcu czy schemacie. Ludzkie zachowania w tym ujęciu są w znacznym stopniu przewidywalne, przynajmniej potencjalnie. Oznacza to, że znając te schematy i układ bodźców zewnętrznych, możemy określić zbiór modeli zachowań, które wystąpią w danych okolicznościach. Amerykańska badaczka opiera swoje przekonanie na

* AGH Akademia Górniczo-Hutnicza; branicki@agh.edu.pl

1 Cytaty tekstów anglojęzycznych w tłumaczeniu autora. 
założeniu zaczerpniętym z koncepcji Jacques’a Lacana. Według francuskiego psychoanalityka podmiot jest ,programowany” przez język i społeczeństwo. Turkle dodaje do tego jeszcze aspekt biologiczny. Na tej podstawie uczona stawia następującą tezę:

Jesteśmy autentyczni w sposób, w jaki autentyczne mogą być maszyny, a maszyny mogą być autentyczne w sposób, w jaki autentyczni mogą być ludzie (Turkle 2011: 138).

Wedle tego ujęcia, jeżeli istnieje różnica między autentycznością osobową i maszynową, nie jest ona istotna, ale techniczna. Można zatem domniemywać, że wraz z rozwojem nauk technicznych różnica ta zostanie całkowicie zniesiona. Wszystko sprowadza się więc do kwestii precyzyjnego programowania. Przedstawione tutaj rozumowanie wydaje się spójne, jednak warto pamiętać, że opiera się ono na dyskusyjnym założeniu, definiującym ludzką podmiotowość jako zbiór schematów uwarunkowanych biologicznie, społecznie i językowo. Z perspektywy dezintegracji pozytywnej rysuje się inna hipoteza. Zakłada ona, że taki redukcjonistyczny obraz człowieka nie znajduje potwierdzenia w badaniach empirycznych i jest przykładem błędu logicznego typu pars pro toto.

Drugim zjawiskiem, w odniesieniu do którego próbuje się podważyć dotychczasowy sens autentyczności, są środki farmakologiczne, mogące w coraz większym stopniu ingerować w strukturę psychiczną człowieka. Fredrik Svenaeus twierdzi, że to zjawisko - głęboko zakorzenione w kulturze Zachodu - podaje w wątpliwość znaczenie kategorii ,autentycznej zmiany siebie" (authentic self-change). Autor w następujący sposób określa to tradycyjne znaczenie:

(...) zmiana w sobie powinna być wynikiem żmudnej pracy nad sobą [oryg. self-work-przypis autora], w ramach której człowiek odkrywa głębokie warstwy swojego „,ja” (nieświadomość) i uświadamia sobie, kim naprawdę jest i kim powinien się stać (Svenaeus 2009: 171).

Warto przyjrzeć się założeniom, na których opiera się ta koncepcja rozwoju. Pierwsze z nich wskazuje na istnienie prawdziwej tożsamości człowieka, niebędącej wynikiem pracy nad sobą. Podmiot nie ma wpływu na jej kształt. Może ją odkryć lub w pewnym sensie o niej zapomnieć czy też ją zignorować. To odniesienie człowieka do jego ,prawdziwego ja" ma wpływ na jego życie, ale samej tożsamości nie zmienia. Drugie założenie kryje się za powinnościowym aspektem tej koncepcji. Powinność ewokuje pytanie o kryteria, na podstawie których można odpowiedzieć na pytanie o kierunek zmian. Założeniem jest tutaj określony zbiór norm lub wartości. Trzecie założenie, wedle którego autentyczna zmiana jest wynikiem żmudnej pracy, zostało bezpośrednio podane w wątpliwość za sprawą skuteczności współczesnej farmakologii. Poziom serotoniny i innych neurotransmiterów w mózgu może zostać podniesiony zarówno przez farmakoterapię, jak również przez psychoterapię. W wymiarze psychologicznym jest to związane m.in. z podniesieniem poczucia własnej wartości. Problem sygnalizowany przez Svenaeusa jest następujący: jeżeli farmakoterapia i psychoterapia powodują takie same skutki w sferze biochemicznej i psychicznej, to dlaczego mamy twierdzić, że zmiana dokonana za pomocą pierwszego środka nie jest autentyczna (Svenaeus 2009: 175-176). Istnieje jednak ważna, choć subtelna różnica. Szwedzki autor odwołał się do badań klinicznych przeprowadzonych przez Petera Kramera (zob. Kramer 1995). Psychiatra ten stwierdził, że część pacjentów z zaburzeniami depresyjnymi po zastosowaniu 
farmaceutyków mówiło, że doświadczyli „stania się sobą”, lecz pozostali pacjenci twierdzili, że pomimo poprawy nastroju, mają poczucie „utraty siebie” (Svenaeus 2009: 171). Jest dość prawdopodobne, że w grupie osób poddanych psychoterapii również można wyróżnić takie dwa podzbiory. Kluczem do zrozumienia tego zjawiska wydaje się kategoria ,prawdziwego ja”, z którą blisko związane jest pojęcie autentyczności. Kazimierz Dąbrowski w bardzo wnikliwy sposób analizował fenomen autentycznego rozwoju. Aby przeanalizować zarysowaną powyżej problematykę, sięgnę do koncepcji dezintegracji pozytywnej.

\section{AUTENTYCZNOŚĆ JAKO NATURALNOŚĆ}

Związek autentyczności i naturalności był akcentowany w koncepcji Jana Jakuba Rousseau. W jego ujęciu granica między naturą jako taką i naturą ludzką jest płynna. Robert Spaemann pisze, że według autora Emila przeznaczeniem ludzkiego bytu jest „czyste poczucie istnienia" (Spaemann 2011: 36). Przedmiotem naszego zainteresowania jest opis natury ludzkiej, którą można potraktować jako jeden z wymiarów natury jako takiej. Naturalność ludzkich zachowań, przy pewnym odczytaniu niespójnej koncepcji Rousseau, wyraża się w spontanicznej szczerości i wyklucza jakąkolwiek intencjonalną, celową ingerencję. Jacques Maritain pisał na temat znaczenia szczerości w koncepcji Rousseau:

Polega ona na nietykaniu tego, co każdy odkrywa w sobie w każdej chwili swego życia, z obawy, aby nie naruszyć swego bytu. Od początku i z samego założenia każda praca nad sobą jest zakażona faryzejską hipokryzją (Maritain 2005: 141).

Maritain zauważa, że autor Umowy społecznej sankcjonuje prymat świata marzeń nad rzeczywistością. Szczerość wyraża się tutaj poprzez „wylewanie się w formie czystej spontaniczności afektywnej" (Maritain 2005: 155). Odrzucenie korespondencyjnej koncepcji prawdy jest pochodną uznania emocji za kluczowy element ludzkiej natury. Rozum tworzący świat myśli jest postrzegany jako cenzor odpowiedzialny za zniekształcanie autentycznego, ludzkiego doświadczenia. Tekstu Wyznań Rousseau nie należy zatem traktować jako rzetelnego sprawozdania z wydarzeń i przeżyć z przeszłości autora. Jest to raczej wynik bezrefleksyjnego przelewania na papier stanów emocjonalnych, które towarzyszyły autorowi podczas pracy nad Wyznaniami. Przeszłe wydarzenia stanowią tu jedynie klucz wywołujący ciąg aktualnie przeżywanych stanów. Michał Warchala pisze na ten temat:

(...) Rousseau nie interesuje się „faktami”, prawdą (w tym wypadku jest to prawda jego własnego życia) traktowaną jako zbiór obiektywnych danych. Jak zauważa w szkicach do Wyznań, fakty są jedynie ,zewnętrznymi oznakami” odsyłającymi do stanów duszy. (...) Wnętrze człowieka to chaos różnorakich, często sprzecznych uczuć, które można opisać jedynie „stylem nierównym i naturalnym”. Ten styl „sam będzie częścią mojej historii” - słowa i zdania staną się w pełni przezroczyste i nierozerwalnie związane z treścią, którą wyrażają" (Warchala 2006: 60).

Jest to zatem rodzaj testu projekcyjnego. Jednak opisując nawet tak chaotyczny świat wewnętrzny, trudno całkowicie pominąć rozum. Można zatem stwierdzić, że podjęcie działalności 
pisarskiej jest dla Rousseau pewnym ustępstwem na drodze do osiagnięcia ostatecznego celu, którym jest niezmącone odczuwanie samego siebie (Spaemann 2011: 36-37).

Powstaje jednak pytanie, dlaczego właściwie szwajcarski myśliciel wykluczył rozumność z zakresu tego, co jest autentycznie ludzkie. Jako rozumność przyjmuję funkcję, która wyraża się w wartościowaniu. Dokonuje się ono przy użyciu kategorii prawdy i fałszu, ewentualnie także modalności: możliwość, konieczność. Robert Spaemann sugeruje, że jest to związane z postulatem Rousseau, mówiącym o absolutnej tożsamości człowieka. Niemiecki uczony pisze:

Rousseau nie poszukuje ukrytej prawdy, lecz poszukuje prawdy jako nieskrytości. Nie poszukuje po kartezjańsku - pewności w świecie niepewności, lecz poszukuje świata pewności. To poszukiwanie poprowadzi go w przeciwstawnych kierunkach. Rozdwojenie bytu i pozoru można przecież znieść przez zniesienie bytu lub zniesienie pozoru. Tam, gdzie pozór staje się absolutny, problem jest rozwiązany tak samo jak tam, gdzie absolutny staje się byt. Gdzie pozór całkowicie pochłonął byt, tam on sam stał się bytem (Spaemann 2011: 57).

Autentyczność, którą osiąga się w absolutnej tożsamości, można zrealizować - jak zauważa Spaemann - poprzez pełny powrót do natury lub całkowite „wynaturzenie”, czyli stanie się obywatelem. Rysuje się tutaj podstawowy dylemat, który opisywał Rousseau. Po pierwsze opisany postulat absolutnej tożsamości. Po drugie autentyczność jest pojmowana jako amorficzność. Maritain pisze: „Istnieje „szczerość” materii, która byłaby ostatecznie doskonała tylko w oddaleniu od wszelkiej formy, w czystym rozproszeniu, w czystej potencjalności (Maritain 2005: 141). Francuski personalista wskazuje, że człowiek w takim ujęciu, będąc samą uczuciowością, staje się sobą, gdy „ulegnie zupełnemu rozkładowi” (Maritain 2005: 142). Posługując się terminologią Arystotelesa, do której odwołuje się Maritain, można stwierdzić, że według autora Emila człowiek autentyczny jest czystą formą albo pozbawioną formy materią. Jest to konsekwencja odejścia od teleologicznego rozumienia natury. Byt, który jest w pełni uformowany, nie dąży do żadnego celu rozwojowego, ponieważ jest w pełni zaktualizowany. Czysta materia wedle Rousseau nie powinna być uformowana poprzez wprowadzenie wymiaru habitualnego, ponieważ byłoby to równoznaczne z ograniczeniem spontaniczności. Przypadkiem szczególnym jest jedynie całkowita habitualizacja ludzkiej egzystencji, ale wówczas człowiek staje się niejako samą formą.

W koncepcji Rousseau nastąpiło zerwanie także z inną, istotną częścią tradycji intelektualnej. Alessandro Ferrara i Fred J. Evans piszą:

Od stoików do Kanta praca nad emocjami podejmowana z uwagi na normy społeczne była postrzegana jako prowadząca do erozji, a następnie rozbicia tożsamości [oryg. the self-przypis autora], natomiast praca nad emocjami, która była podejmowana z uwagi na własne moralne przekonania, nie była rozumiana jako całkiem bezpieczna, ale rzeczywiście sprzyjająca pozytywnemu poczuciu wewnętrznej siły, witalności i spójności (Ferrara, Evans 1993: 104).

Od czasów Sokratesa i Platona - jak podkreślają cytowani autorzy - wierność uznanym osobiście zasadom etycznym była postrzegana jako objaw autonomii i siły charakteru. Ferrara i Evans przekonują na podstawie analizy dzieła Nowa Heloiza, że Rousseau podał w wątpliwość ten pogląd. Wedle tego ujęcia instrumentalne potraktowanie sfery afektywnej - nawet jeżeli celem jest wierność przyjętym zasadom etycznym - prowadzi do osłabienia, 
Autentyczność osobowa w perspektywie teorii dezintegracji pozytywnej

a w końcu rozbicia tożsamości (Ferrara, Evans 1993: 104). Paradoks polega jednak na tym, że pozostawanie w stanie afektywności nietkniętej przez żadne reguły czy formy oznacza trwanie w permanentnym rozbiciu tożsamości. W ujęciu Dąbrowskiego stanu chronicznej i bezcelowej dezintegracji nie można określić jako pozytywnego.

\section{AUTENTYCZNOŚĆ JAKO ROZWÓJ}

W koncepcji Kazimierza Dąbrowskiego autentyczność mieści się w zakresie „czynnika trzeciego". Czynnik pierwszy ma charakter konstytucjonalny i obejmuje uwarunkowanie biologiczne. Czynnik drugi oznacza zbiór uwarunkowań środowiskowych i społecznych. Czynnik trzeci zaś ma charakter autentyczny i autonomiczny. Te dwa elementy są ze sobą ściśle związane. Można stwierdzić, że tylko działania autonomiczne są działaniami autentycznymi. Polski uczony pisze:

(...) przy odpowiednim wyposażeniu jednostki pod względem potencjału rozwojowego występują tendencje przeciw zbyt silnym i automatycznym determinantom biologicznym tudzież determinantom środowiska społecznego (Dąbrowski 1996: 47).

Dąbrowski wskazuje, że może wiązać się to również z częściowym przekroczeniem uwarunkowań biologicznych, a także pierwotnych cech własnego typu psychologicznego. Autonomia względem tych dwóch determinant stwarza zatem podstawy do dokonania autentycznego wyboru. Dąbrowski pisze o przełomie w życiu jednostki, który pojawia się w wyniku zaistnienia czynników autonomicznych i autentycznych:

Zaczynają działać dynamizmy typowe dla poziomu dezintegracji spontanicznej wielopoziomowej, jak zdziwienie w stosunku do siebie, zaniepokojenie sobą, poczucie niższości w stosunku do siebie, poczucie wstydu i winy, nieprzystosowanie pozytywne, instynkt twórczy wielopoziomowy i inne. Pozwalają one zyskać dystans do siebie samego (ibidem).

Autonomia stanowi zatem warunek umożliwiający dokonywanie autentycznych wyborów. Szczególnie ważne są decyzje związane z koniecznością odrzucenia części samego siebie. Nasuwa się w związku z tym pytanie o kryterium takiego działania. Można bowiem stwierdzić, że w świetle dezintegracji pozytywnej nie wszystko, co jest częścią człowieka, musi być przez niego uznane. Podmiot może nie utożsamiać się z częścią swojej psychiki czy impulsywności biologicznej. Według polskiego uczonego to właśnie wtedy wzrasta stopień autentyczności. Jednocześnie ten wybór nie jest arbitralny czy spontaniczny, ale dokonuje się według określonych, uniwersalnych kryteriów, którymi są wartości. Dąbrowski pisze:

Poznanie siebie to dochodzenie przez doświadczenie i myślenie do oceny tego, co nie jest „mną we mnie", i tego, co już zaczyna być mna, choć nie jest jeszcze utrwalone, a także tego, co powinno być mną, choć jeszcze mną nie jest, ale do czego dążę uporem woli, myśleniem, ciszą kontemplacji i wysiłkiem dnia codziennego (Dąbrowski 1986: 77).

Warto zaznaczyć, że autor dezintegracji pozytywnej nie był zwolennikiem konstruktywizmu antropologicznego i aksjologicznego. Uważał on, że osobowość jest zbudowana 
z dwóch esencji: indywidualnej i wspólnej. Cechy składające się na te istoty podlegają jedynie zmianom ilościowym, natomiast pod względem jakości pozostają stałe. Dąbrowski stwierdza:

W trakcie rozwoju mogą wejść do osobowości inne właściwości obok esencjalnych, ale nie zmienią one miejsca i znaczenia centralnych właściwości esencjalnych (Dąbrowski 1996: 122-123).

Jako przykłady cech należących do istoty ogólnej polski psycholog wymienia empatię, autentyzm, autonomię i odpowiedzialność. Warto zaznaczyć, że empatia jest pojmowana przez Dąbrowskiego jako funkcja racjonalna. Podlega ona swoistej weryfikacji wówczas, gdy spotykamy się z zachowaniami, które oceniamy negatywnie. Na temat doświadczenia empatii w takiej sytuacji pisze polski psycholog:

Umożliwia ona spojrzenie na człowieka nie jako na osobistego wroga, ale jak na kogoś, kto, jeśli postępuje źle, to - być może - dlatego, że skłaniają go do tego czynniki odziedziczone i wpływy środowiska oraz niski poziom samoświadomości. Empatia pozwala na przyjęcie wobec takiego człowieka postawy ponadosobistej, postawy rozumiejącej (Dąbrowski 1986: 87).

Wymienione cztery elementy składające się na istotę ogólną są ze sobą związane. Człowiek o niskim poziomie empatii, który nie rozumie siebie i innych, nie jest również zdolny do brania odpowiedzialności za swoje czyny. Nie oznacza to, że obiektywnie nie jest za nie odpowiedzialny, ale takie doświadczenie jest pozbawione głębszego wymiaru egzystencjalnego. W takiej sytuacji, kiedy człowiek nie ma poczucia sprawczości w odniesieniu do własnych działań, skutki jego czynów mogą być dla takiej osoby destrukcyjne. Empatia oznacza przede wszystkim rozumienie samego siebie i dlatego człowiek, który ma rozwiniętą tę funkcję, przy świadomości deterministycznego tragizmu niektórych swoich decyzji i czynów może udźwignąć odpowiedzialność, która z nich wynika. Wydaje się, że właśnie w ten sposób rozwija się w podmiocie przestrzeń autentyczności i autonomii. Kiedy człowiek uznaje za własne także to, co w nim samym budzi niezadowolenie i dezaprobatę, otwiera się możliwość dokonania autentycznego wyboru.

Wydaje się uprawnionym twierdzenie, że w świetle koncepcji dezintegracji pozytywnej autentyczność jest realizowana przez rozwój. Wzrost poziomu autentyczności jest znakiem rozwoju, a zarazem autentyczność jest warunkiem umożliwiającym rozwój. Człowiek, którego zachowanie jest determinowane przez zjawiska społeczne i impulsy biologiczne, nie może przejść na wyższy poziom rozwoju. Jeżeli nawet wpływ otoczenia społecznego i konformistyczna postawa osoby implikują zachowania obiektywnie dobre, to mogą one pozostawać nieistotne dla rozwoju z uwagi na brak elementu autentyczności. Myśli, uczucia i zachowania nie należą do podmiotu, w którym się znajdują. Są obce, narzucone lub sprytnie zasugerowane. Dopiero osobiste przeżywanie świata wartości stwarza możliwość aktualizacji sfery zaliczanej do zakresu czynnika trzeciego. Odkrycie tej sfery może dokonać się dzięki obecności osób, które same osiagnnęły już ten poziom rozwoju. Autentyczność wydaje się konstytutywną cechą relacji osobowej między mistrzem i uczniem. Klasycznym przykładem jest zdolność nauczyciela do przyznania się do błędu z pokorą, ale jednocześnie bez pobłażania sobie. Przejawia się tutaj brak bezwzględnego perfekcjonizmu lub lękowego przerzucania odpowiedzialności na innych. Jednocześnie człowiek świadomie doznaje przykrości 
wynikającej z popełnionego błędu, podejmując wysiłek, aby nie doszło do jego powtórzenia. Wydaje się, że ta koncepcja jest bliższa klasycznemu ujęciu, które możemy w osobistej formie odnaleźć w Wyznaniach świętego Augustyna. W przeciwieństwie do tego, w dziele o tym samym tytule autorstwa J.J. Rousseau możemy dostrzec takie elementy narracji, które dają podstawy do sformułowania tezy, że autor odrzucił jakąkolwiek formę oceny. Zasadnicza różnica między dziełami Augustyna i Rousseau sprowadza się zatem do tego, że Rousseau odrzuca procedurę wartościowania.

Kazimierz Dąbrowski twierdzi, że wartościowanie nie jest czynnością arbitralną:

(...) wartości jako normy są jednocześnie zjawiskami empirycznymi i normatywnymi, przeżywanymi subiektywnie, sprawdzalnymi i wymierzalnymi obiektywnie, jeżeli podejdziemy do tego zagadnienia od strony rozwoju całej psychiki danej osoby i jej zespołu funkcji, a szczególnie funkcji uczuciowych, które są główną podstawą formowania się hierarchii wartości i rozwoju dyspozycji psychicznych do ich realizacji (Dąbrowski 1974: 40).

Rozwój sfery czynnika trzeciego nie oznacza izolacji pozostałych wymiarów osoby. Dąbrowski przekonuje, że proces ten ma sens tylko wtedy, gdy obejmuje wszystkie sfery człowieka, w tym także instynkt. Autor dezintegracji pozytywnej wyjaśnia to zjawisko, odwołując się do przykładu instynktu samozachowawczego, który na najniższym poziomie obejmuje tylko siebie samego jako byt fizyczny. Na wyższym poziomie człowiek zaczyna odczuwać potrzebę zachowania swojej struktury psychicznej, moralnej czy dobrego imienia. Wreszcie instynkt samozachowawczy może też objąć członków rodziny, a potem każdej osoby. Istnieje przepaść miedzy dążeniem do ochrony jedynie własnej cielesności a dążeniem do ochrony każdej napotkanej osoby. Według Dąbrowskiego wyższa wartość tej drugiej postawy jest empirycznym faktem.

\section{AUTENTYCZNOŚĆ W OBLICZU ŚMIERCI}

Kazimierz Dąbrowski uważał, że autentyczność weryfikuje się w sytuacjach granicznych, a przede wszystkim w obliczu śmierci. Nadaje to jego koncepcji wymiar egzystencjalny. Doświadczenie śmierci i umierania jest według polskiego uczonego zjawiskiem wielowymiarowym. Krytycznie oceniał on pragmatyczne podejście do przeżywania śmierci. Świadomość, że taki moment nastąpi, ma pomagać w ocenie tego, co jest ważne oraz w podejmowaniu decyzji. Dąbrowski następująco komentuje tego rodzaju, instrumentalne podejście do odchodzenia:

Śmierć stanowi tutaj jeszcze jeden bodziec do lepszego zorganizowania życia, do lepszego opracowania businessu z zapewnieniem sukcesu w tym życiu. Nie ma tutaj autentycznego przeżycia śmierci, wyjścia poza sprawy biologiczne, poszukiwania transcendencji. Nie ma tutaj wstrząsów uczuciowych. Jest postawa, która nie wyraża autentycznej filozofii egzystencjalnej, autentycznych konfliktów wewnętrznych, jaspersowskiej ,pasji nocy” (Dąbrowski 1996: 111).

W zacytowanym tekście autor dezintegracji opisuje cechy charakterystyczne dla czterech stadiów przeżywania śmierci. Polski uczony w jednoznaczny sposób dokonuje ich wartościowania. W najniższym stadium człowiek właściwie nie jest świadomy własnej śmierci. Nie 
chodzi tutaj Dąbrowskiemu o wiedzę deklaratywną, ale o autentyczne przeżycie wynikające $\mathrm{z}$ uświadomienia sobie nieuchronności własnej śmierci. Człowiek w tym stadium rozwoju nie potrafi nawet wyobrazić sobie siebie jako umierającego. Lęk przed umieraniem ma charakter czysto biologiczny i jest pozbawiony wymiaru egzystencjalnego. Egoistyczna ochrona własnego bytu łączy się z brakiem empatii, a często także z okrucieństwem wobec innych osób. W drugiej fazie przeżywanie śmierci ma charakter impulsywny i ambiwalentny, dlatego nie dochodzi do pogłębienia refleksji. Labilność nastrojów jest jedną z ważnych przyczyn tego stanu. Dopiero w trzecim stadium pojawia się kluczowe zjawisko nazwane przez Dąbrowskiego „instynktem śmierci cząstkowej”. Polski psycholog pisze, że jest to „(...) wewnętrzna transformacja - osłabienie cech »niższych«, mniej ludzkich przy rozwoju i umacnianiu właściwości wyższych" (Dąbrowski 1996: 114). To zjawisko jest związane z przeżyciem hierarchiczności w środowisku wewnętrznym podmiotu. Śmierć cząstkowa oznacza zanikanie tego, co w człowieku prymitywne. Dąbrowski nie ma tutaj na myśli tendencji do wypierania biologicznego wymiaru jednostki, ale świadomość, że jest on częścią złożonego bytu osobowego. Pewne tendencje ulegają atrofii, to znaczy jakaś część człowieka umiera i dlatego jest to proces trudny, dramatyczny, a jednocześnie twórczy. Znakiem właściwym tego stadium jest słabnięcie lęku przed własną śmiercią, przy jednoczesnym pogłębieniu rozumienia śmierci innych osób. Jest to związane z przekraczaniem własnego egoizmu oraz wzrostem poczucia odpowiedzialności za egzystencję i rozwój innych ludzi. Dąbrowski pisze:

Potrzeba związków wieczystych rośnie i ustala się jako wartość nieprzemijająca. Przychodzi pełna zdolność poświęcenia swojego życia dla „sprawy”. Jest to postawa autentyczna, którą wyrazili swoim życiem i opiniami tacy ludzie, jak Sokrates, Joanna d'Arc, Ojciec Kolbe, dr Korczak i inni (Dąbrowski 1996: 115).

Człowiek według autora dezintegracji pozytywnej nie może być autentyczny, znajdując się w pierwszym stadium rozwoju, ponieważ nie może realizować możliwości, które są charakterystyczne dla ludzi. Nie można być autentycznie człowiekiem, aktualizując jedynie biologiczny wymiar ludzkiego bytu. Kiedy sfera instynktów zostaje zaangażowana w realizację esencjalnej płaszczyzny osoby, dopiero wówczas można mówić o autentycznym przeżywaniu cielesności jako części ludzkiej egzystencji.

Według Dąbrowskiego integralną częścią doświadczenia ludzkiego jest przeżywanie śmierci. Choć brzmi to paradoksalnie, mam tutaj także na myśli przeżywanie własnej śmierci. Śmierć jest opisywana jako proces, a nie jednorazowy akt. Obumieranie jest nieodłączną częścią rozwoju. Wydaje się uprawnionym twierdzenie, że według polskiego uczonego umieranie jest stale związane z ludzkim życiem, przynajmniej w znanej nam formie. Takie ujęcie zagadnienia przywodzi na myśl koncepcję Heraklita z Efezu. Filozof ten jest autorem znanej frazy: „Istota lubi się skrywać” (Kirk, Raven i Schofield 1999: 195). Słowo „istota” ma oddawać grecki termin physis. Pierre Hadot zwraca uwagę, że w czasach Heraklita termin ten nie oznaczał natury jako całości oraz praw rządzących zjawiskami. Francuski historyk wskazuje dwa możliwe znaczenia tego pojęcia. Po pierwsze może to być zbiór cech konstytutywnych dla danego przedmiotu czy też właściwa jego natura. Po drugie physis mogło oznaczać proces stawania się rzeczy, ich genezy i wzrostu (Hadot 2006: 7). Słowo philein, 
oddane w polskim przekładzie przez czasownik „lubić”, nie ma konotacji emocjonalnej, ale oznacza naturalną lub nawykową tendencję. Hadot pisze, że grecki termin krupthestai, którego użył Heraklit, pochodzi od czasownika oznaczającego „chować, grzebać”. Na tej podstawie francuski uczony proponuje interpretację aforyzmu filozofa z Efezu, w której physis oznacza narodziny, a krupthestai znikanie lub śmierć (Hadot 2006: 8-9). Analizowane zdanie mędrca z Efezu wyrażałoby myśl, że życie jest umieraniem. Śmierć jest właśnie ową zasłoną, która skrywa życie.

Relacja koncepcji dezintegracji pozytywnej i filozofii Heraklita ma charakter złożony. Warto ją jednak prześledzić. Jeżeli bowiem jest możliwe potwierdzenie pewnych intuicji egzystencjalnych u tak odległych czasowo i metodologicznie myślicieli, można uznać, że jest to swoisty argument zwiększający prawdopodobieństwo tych stwierdzeń. Wydaje się bowiem, że w ograniczonym, ale ważnym zakresie te koncepcje są podobne. Mam na myśli przede wszystkim rozumienie bytu ludzkiego jako struktury dynamicznej. Drugim punktem zbieżnym jest przekonanie obydwu myślicieli, że ów dynamizm jest nierozerwalnie związany z doświadczeniem śmierci. Trzecie podobieństwo odnosi się do myśli, że człowiek może przezwyciężyć determinizm, świadomie kierując swoim życiem. Kirk, Raven i Schofield piszą:

(...) Heraklit odrzuca częsty u Homera pogląd, że człowiek nie zawsze może odpowiadać za swoje czyny. Daimon tutaj to po prostu osobiste przeznaczenie. Mając nad nim pewną władzę, człowiek kieruje swoim losem. Nie decydują o nim zewnętrzne, często kapryśne moce, działające prawdopodobnie za pośrednictwem „ducha” przypisanego każdemu przez los czy Fatum (Kirk, Raven, Schofield 1999: 213).

Według Heraklita daimon to charakter człowieka. Należy go dobrze poznać, aby ostatecznie dążyć do jego przekroczenia. Heraklit pisze: „Szukałem samego siebie” (Kirk, Raven, Schofield 1999: 212). Zestawiając to stwierdzenie z innymi fragmentami, angielscy historycy piszą: ,„szukając siebie«, człowiek prawdopodobnie odkrywa, że dusza rozciaga się poza jednostkę" (Kirk, Raven, Schofield 1999: 213). Podobnie jak w koncepcji Dąbrowskiego, człowiek odnajdując siebie, jednocześnie siebie przekracza. Wyraża się to - jak pisał Dąbrowski - w gotowości do poświęcenia dla sprawy. Heraklit krytykuje też uleganie niskim namiętnościom: „Męża, gdy jest pijany, chłopak niedojrzały prowadzi. Idzie, zataczając się, nieświadom dokąd, mając wilgotną duszę" (Kirk, Raven, Schofield 1999: 206). Z drugiej strony znajdujemy pochwałę postawy walecznej: „Dusze zabite na wojnie są czystsze niż zmarłe w chorobach” (Kirk, Raven, Schofield 1999: 213). Kirk, Raven i Schofield uważają, że najbardziej prawdopodobna jest interpretacja zgodna z ówczesną, naiwną wiedzą przyrodniczą. Niewykluczone, że tkwią tutaj również głębsze intuicje egzystencjalne. Gdyby bowiem Heraklit chciał przekazać jedynie twierdzenia dotyczące przyrody, to prawdopodobnie nie posługiwałby się tak wieloznacznymi sformułowaniami. Pozytywna konotacja antropologiczna takich terminów jak „ogien” oraz „wojna” mogą także symbolizować świadomą walkę wewnętrzną. Tutaj znowu można odnaleźć pewną zbieżność z koncepcją Dąbrowskiego. Człowiek może doświadczać i przeżywać umierania samego siebie w sposób pasywny, godząc się biernie na upływ życia, przemijanie przeżyć, myśli, emocji. Natomiast 
postawa, którą wydają się zalecać Heraklit i Dąbrowski jest aktywna i zaangażowana. Można dopatrzyć się w niej pewnego elementu specyficznej autoagresji. Człowiek sam doprowadza pewne obszary siebie do atrofii, śmierci. Jest to rodzaj wojny wewnętrznej. Śmierć cząstkowa, o której pisał Dąbrowski, nie jest wynikiem przemijania, ale aktywności samego podmiotu. Dąbrowski pisał o potrzebie podporządkowania swoich czynów wyższym wartościom, co pozwala przezwyciężyć egoizm. Podobnie Heraklit pisze, że należy zrezygnować z partykularnej racjonalności na rzecz uniwersalnego logosu. Dochodzenie do tego, co powszechne, dokonuje się według obydwu myślicieli na drodze wewnętrznych poszukiwań. Heraklit pisze: „Granic duszy nie znajdziesz, choćbyś przeszedł wszystkie drogi. Tak głęboki jest jej logos" (Legowicz 1968: 82). To dzięki logosowi możliwa jest jedność przeciwieństw. Mimo współwystępowania życia i śmierci, tego, co skończone i nieskończone, ograniczone i nieograniczone, mimo trwania ciągłej wojny, a może właśnie dzięki temu panuje ład. W nieco podobnym duchu pisze Dąbrowski:

Od impulsywnego protestu przeciw śmierci, poprzez jej autentyczne przeżywanie, poprzez historię długiego ciągu codziennych lub prawie codziennych agonii z nią związanych, zaczyna przebłyskiwać droga do transcendencji konkretnej, w której zarysowują się możliwości zachowania najgłębszych wartości, które wybraliśmy świadomie, przeżyliśmy, afirmowaliśmy i rozwijaliśmy, i które są dla nas ważniejsze od naszego życia (Dąbrowski 1996: 116).

Autentyczne przeżywanie umierania polega na świadomej konfrontacji człowieka z tym, co nieuchronne. Heraklit pisał o sile przeznaczenia. Przekonanie o fatalistycznej sile losu było mocno zakorzenione w kulturze starożytnej Grecji. Powstająca filozofia była elementem kultury, w ramach której zrodziło się przekonanie o wartości osobistej postawy. Filozofia właściwie od samych początków dąży do wyeliminowania lęku przed śmiercią. Nie można wprawdzie uniknąć samego faktu śmierci, ale świadomie wychodząc jej naprzeciw, człowiek może przestać się jej lękać.

Wydaje się, że w obliczu śmierci człowiek właściwie nie może już udawać. Wszystkie mechanizmy obronne muszą skapitulować. Jednak w sensie egzystencjalnym człowiek pogrążony w iluzjach jest pozbawiony możliwości autentycznego odejścia, nawet jeśli w sensie biologicznym do niego dochodzi. Soren Kierkegaard nazywał taki stan rozpaczą. Nie jest to doświadczenie przeżywane w pełni świadomie. Duński egzystencjalista nazywał rozpacz „chorobą na śmierć”. Kierkegaard pisał:

Być chorym na śmierć to znaczy nie być zdolnym do śmierci, ale nie chodzi tu o nadzieję życia - nie, beznadziejność polega na tym, że człowiek nie ma ostatniej nadziei, nadziei na śmierć (Kierkegaard 1982: 152).

Ta niemożliwość wiąże się ściśle z brakiem autentyczności. Człowiek nie jest autentyczny, ponieważ - jak wskazuje Aleksander Bobko - nietrafnie siebie zrozumiał. Człowiek, który nie jest sobą, jest nieautentyczny, nie może w sensie egzystencjalnym doświadczyć własnej śmierci. Bobko pisze:

Nieautentyczna egzystencja nie może się nawet zakończyć, nieautentyczny podmiot nie może umrzeć, bo przecież tak naprawdę nigdy go nie było (Bobko 2007: 110). 
Autentyczność osobowa w perspektywie teorii dezintegracji pozytywnej

Człowiek zbudował zbiór iluzji, które odcinają go od niego samego i dlatego nie może podjąć żadnej decyzji, która dotyczy jego prawdziwego ,ja”.

\section{AUTENTYCZNOŚĆ W ŚWIECIE TECHNIKI}

Dzięki farmakologii można zmienić poziom neuroprzekaźników i w konsekwencji poprawić nastrój. Jak pisałem, wśród badanych była grupa ludzi, którzy twierdzą, że dzięki lekom „odnaleźli siebie”. Warto jednak pamiętać o drugiej grupie, która mimo poprawy nastroju opisuje swoje doświadczenie jako „utratę siebie”. Nasuwa się hipoteza, że w tym drugim zbiorze znajdują się ludzie o najwyższym potencjale rozwojowym, ocenianym według kryteriów dezintegracji pozytywnej. Są to osoby, o których Dąbrowski pisał, że są „skazani na rozwój”. To w tej grupie prawdopodobnie znajdują się jednostki, które tylko przez doświadczenie niemal codziennej śmierci cząstkowej mogą odnaleźć siebie. Nie jest również wykluczone, że w pierwszym zbiorze przynajmniej niektóre osoby po pewnym czasie zaczną odczuwać tęsknotę za czymś więcej niż dobry nastrój.

Warto zaznaczyć, że według Dąbrowskiego człowiek poprzez rozwój może stać się osobowością. Jak zauważa Anna Mróz, oznacza to, że nie każda jednostka ma osobowość (Mróz 2008: 44). Polski psycholog pisze:

Osobowość to samouświadomiona, samowybrana, samopotwierdzona i samowychowująca się jedność podstawowych właściwości psychicznych, realizująca swój hierarchiczny, konkretny ideał indywidualny i społeczny (Dąbrowski 1982: 40).

Podstawą osobowości jest zatem samowiedza. Jest ona warunkiem możliwości decydowania o sobie. Poprawa nastroju za pomocą środków farmakologicznych nie może zatem wpływać na osobowość w rozumieniu Dąbrowskiego. Według polskiego uczonego nie można stać się osobowością, pomijając zmaganie z samym sobą. Z tej perspektywy jednostka, której działania są zdeterminowane przez nastroje, nie jest osobowością. Wolna decyzja może być podejmowana tylko wówczas, gdy człowiek potrafi zdystansować się wobec instynktów, nastrojów i presji społecznej.

Sharon Turkle przyjęła założenie, że człowiek jest całkowicie uwarunkowany przez język, społeczeństwo i biologię. Warto zwrócić uwagę, że jest to powrót do tezy dominującej w kulturze jeszcze przed powstaniem filozofii. Jest to bowiem pogląd mówiący o fatalistycznym zdeterminowaniu zachowania człowieka. Chociaż argumentacja jest inna, to teza jest właściwie ta sama. Kazimierz Dąbrowski jest w tym względzie kontynuatorem tradycji zapoczątkowanej przez grecką filozofię. Starałem się udokumentować tę tezę przez porównanie jego koncepcji z filozofią Heraklita. Z pewnością takich analogii można odnaleźć znacznie więcej. Dąbrowski przekonuje, że jest możliwe przekroczenie sfery biologicznej, a także własnego typu psychologicznego. Autonomia nie jest jednak w tym ujęciu wartością samą w sobie. Jest raczej warunkiem umożliwiającym podjęcie autentycznej decyzji o przekroczeniu swojego egoizmu. Znakiem, który wskazuje, że ten cel rozwojowy został osiagnięty, jest przeświadczenie, że życie innych osób jest ważniejsze niż własne.

W przeciwieństwie do tego Turkle przyjęła jedno z rozwiązań zaproponowanych przez Rousseau. Pisałem, że według autora Emila rozdwojenie bytu i pozoru można wyeliminować 
przez zniesienie jednego z tych elementów. Wydaje się, że amerykańska uczona wybiera wariant polegający na absolutyzacji pozoru. Prawda nie jest relacją między zdaniem a rzeczą, ale nieskrytością symptomu, znaku. Mamy zatem postmodernistyczną śmierć podmiotu. Mając na uwadze koncepcję Dąbrowskiego, można to ująć w terminologii Kierkegaarda i uznać za chorobę na śmierć, a dążenie do zatarcia granicy między autentycznością maszyny i osoby jest raczej symptomem wskazującym na próbę zamaskowania rozpaczy.

Pozostaje jednak otwartym pytanie, czy teza, którą przyjęła Turkle, jest prawdziwa. Czy zachowanie podmiotu jest pochodną zakodowanych w mózgu programów? Ryszard Tadeusiewicz pisze, że badania procesów neurofizjologicznych, zachodzących w mózgu nie mają zastosowania w leczeniu chorób psychicznych. Krakowski uczony wyjaśnia:

Dzieje się tak, bo pomiędzy wiedzą o zachowaniu pojedynczych neuronów albo ich podlegających badaniom grup, liczących kilka, kilkadziesiąt lub najwyżej kilkaset komórek, a zrozumieniem zachowania mózgu składającego się ze stu miliardów neuronów - zieje poznawcza przepaść. A przecież psychika jest wynikiem pracy całego mózgu, a nie pojedynczych neuronów (Tadeusiewicz 2011: 399).

Tadeusiewicz stwierdza, że nie jest możliwe określenie istoty związku między zjawiskami biochemicznymi i procesami mentalnymi. Być może wynika to tylko z tego, że mózg jest bardzo skomplikowanym przedmiotem badania. Nie można jednak wykluczyć tezy mówiącej o istnieniu pewnej autonomii procesów mentalnych. Uwzględniając koncepcję Dąbrowskiego, można opisać to zjawisko jako proces powstawania osobowości. Zdolność do przekroczenia własnego typu psychologicznego jest prawdopodobnie symptomem wskazującym na autonomizację sfery mentalnej. Polski uczony charakteryzuje ten proces nie tylko jako dystansowanie się wobec wymiaru biologicznego. Autor Dezintegracji pozytywnej pisze:

Przede wszystkim zaś jest to wyraz nasilającego się pozytywnego nieprzystosowania do własnych cech niższego poziomu, a więc wyraz potęgowania się sił autonomicznych i autentycznych własnej psychiki (Dąbrowski 1986: 160).

Konflikt wewnętrzny w omawianej koncepcji jest immanentnym elementem rozwoju, którego efektem jest wzrost poziomu autentyczności. Wyłaniająca się w tym procesie osobowość jest podstawą umożliwiającą podejmowanie wolnych decyzji. Wolności nie można zaprogramować.

Tadeusiewicz pisał o zdolności do samodzielnego tworzenia nowych pojęć, którą posiada sztuczna inteligencja. Polski uczony wskazuje, że oznacza to, iż „(...) maszyna może sama tworzyć nową wiedzę (...)" (Tadeusiewicz 2011: 414). Wydaje się jednak, że zjawisko to nie ma wymiaru egzystencjalnego. Kiedy w umyśle człowieka powstaje nowe pojęcie, może stać się ono podstawą do nowego doświadczenia siebie i rzeczywistości pozapodmiotowej. Pojęcia tworzone przez maszynę mają charakter jedynie funkcjonalny. Stawianie tezy o autentyczności egzystencjalnej sztucznej inteligencji wydaje się nieuzasadnione, ponieważ maszyny nie są zdolne do przeżywania dylematów moralnych i zmagań wewnętrznych z nimi związanych. Pojawiają się jednak próby zbudowania robotów kierujących się w swoich działaniach zasadami etycznymi. Charakterystyczne jest jednak to, że do takich celów wykorzystywane są etyczne koncepcje utylitarystyczne. Zwolennicy takiej aplikacji przyznają, że jest to model 
Autentyczność osobowa w perspektywie teorii dezintegracji pozytywnej

niepotrafiący uchwycić wielu subtelnych aspektów zjawisk etycznych. Dostrzegają jednak pewną szansę. Michael Anderson i Susan L. Anderson piszą:

Ale przynajmniej idea ta pokazuje, że wykonalne jest opracowanie akceptowalnej teorii etycznej, która w zasadzie nadaje się do zakodowania w postaci rachunków (Anderson, Anderson 2010: 60).

Tego typu maszyny są pozbawione wymiaru wewnętrznego zmagania, o którym wiele pisał Dąbrowski. Wykonują obliczenia i na tej podstawie podejmują decyzje. Jest to związane z brakiem emocji. Jednak Michael Anderson i Susan Anderson dostrzegają w tym pewne zalety. Ludzie, ulegając emocjom, często przekraczają reguły etyczne. Po drugie mamy skłonność do faworyzowania osób bliskich. Maszyna postępuje w sposób etyczny i wyrachowany. Amerykańscy autorzy piszą:

Uważamy za bardzo prawdopodobne, że właściwie skonstruowana i wyszkolona maszyna dzięki swej bezstronności będzie zdolna postrzegać emocje człowieka i uwzględniać je w obliczeniach, nawet jeśli sama ich nie odczuwa (Anderson, Anderson 2010: 61).

W wymiarze antropologicznym przypomina to bardziej sterowanie zachowaniem przez socjotechnikę czy manipulację psychologiczną niż proces kształtowania osobowości opisany przez Dąbrowskiego. Zmaganie z własnymi emocjami jest bowiem jednym z konstytutywnych elementów stawania się autentyczną osobowością.

\section{UWAGI KOŃCOWE}

Kazimierz Dąbrowski zaproponował egzystencjalny, a nie techniczny opis człowieka. Stąd wynika specyficzne rozumienie rozmaitych stanów psychicznych. Polski uczony pisze:

Dobre samopoczucie, które przejawia się okresowo, może cechować człowieka rozwijającego się, ale może - w pewnym zespole objawów - towarzyszyć także ciężkim schorzeniom psychicznym (...), natomiast złe samopoczucie może nieraz towarzyszyć procesom przyspieszonego rozwoju (Dąbrowski 1986: 152).

Podnoszenie poziomu nastroju za pomocą środków farmakologicznych może zatem spowodować zahamowanie rozwoju. Ważnym elementem umożliwiającym powstanie autentycznej osobowości jest doświadczenie własnych błędów, dlatego perfekcyjnie realizujący reguły etyczne robot nigdy nie stanie się osobowością. Gdy maszyna autonomicznie tworząca wiedzę popełnia błąd, jest to tylko element procesu kształtowania pojęcia i trudno mówić tutaj o doświadczeniu z jego wymiarem przeżyciowym.

\section{BIBLIOGRAFIA}

Anderson, Michael i Susan Leigh Anderson. 2010. Wychować robota, „Świat Nauki”, nr 11 (231), s. $58-63$.

Bobko, Aleksander. 2007. Myślenie wobec zła, Kraków: Instytut Myśli Józefa Tischnera. 
Branicki, Wacław. 2009. Tożsamość a wirtualność, Kraków: Zakład Wydawniczy NOMOS. Dąbrowski, Kazimierz. 1974. Zdrowie psychiczne a wartości ludzkie, Warszawa: Polskie Towarzystwo Higieny Psychicznej.

Dąbrowski, Kazimierz. 1982. Pasja rozwoju, Warszawa: Polskie Towarzystwo Higieny Psychicznej.

Dąbrowski, Kazimierz. 1986. Trud istnienia, Warszawa: Wiedza Powszechna.

Dąbrowski, Kazimierz. 1996. W poszukiwaniu zdrowia psychicznego, Warszawa: Wydawnictwo Naukowe PWN.

Ferrara, Alessandro i Fred J. Evans. 1993. Modernity and Authenticity: a Study in the Social and Ethical Thought of Jean-Jacques Rousseau, New York: State University of New York Press.

Hadot, Pierre. 2006. The Veil of Isis: an Essay on the History of the Idea of Nature, Cambridge: Belknap Press of Harvard University Press.

Kierkegaard, Soren. 1982. Bojaźń i drżenie. Choroba na śmierć, Warszawa: Wydawnictwo Naukowe PWN.

Kirk, Geoffrey, John Raven i Malcolm Schofield. 1999. Filozofia przedsokratejska, Warszawa: Wydawnictwo Naukowe PWN.

Kramer, Peter. 1995. Wstuchujac się $w$ prozac. Przetom $w$ psychofarmakoterapii depresji, Warszawa: Jacek Santorski \& CO.

Legowicz, Jan. 1968. Filozofia starożytna Grecji i Rzymu, Warszawa: Wydawnictwo Naukowe PWN.

Maritain, Jacques. 2005. Trzej reformatorzy. Luter, Kartezjusz, Rousseau, Warszawa: Fronda, Apostolicum.

Mróz, Anna. 2008. Rozwój osobowy człowieka, Lublin: Towarzystwo Naukowe Katolickiego Uniwersytetu Lubelskiego.

Spaemann, Robert. 2011. Rousseau - czlowiek czy obywatel. Dylemat nowożytności, Warszawa: Oficyna Naukowa.

Svenaeus, Fredrik. 2009. The ethics of self-change: becoming oneself by way of antidepressants or psychotherapy?, „Medicine, Health Care and Philosophy”, no. 12, s. 169-178.

Tadeusiewicz, Ryszard. 2011. Awangarda sztucznej inteligencji - maszyny, które potrafia same tworzyć nowe pojęcia, w: Józef Bremer i Adam Chuderski (red.), Pojęcia. Jak reprezentujemy i kategoryzujemy świat, Kraków: Universitas, s. 395-427.

Turkle, Sharon. 2011. Alone Together. Why We Expect More from Technology and Less from Each Other, New York: Basic Books.

Warchala, Michał. 2006. Autentyczność i nowoczesność. Idea autentyczności od Rousseau do Freuda, Kraków: Universitas.

\section{PERSONAL AUTHENTICITY IN THE PERSPECTIVE OF THE THEORY OF POSITIVE DISINTEGRATION}

The problems discussed in the first part of the paper include relations between phenomenon of authenticity and influence of pharmacology on the human psyche and the issue of artificial intelligence. In the second part of the article the relationship between the notion of authenticity and naturalness has been analysed. In the third part, the above problem has been presented within the framework of Kazimierz Dąbrowski's concept.

Key words: personal authenticity, the theory of positive disintegration, artificial intelligence, death 